\title{
EFFECT OF EXPLANT TYPES AND CYTOKININ TYPES ON GROWTH OF BITTER AND SWEET ALMOND CUTTINGS DURING ESTABLISHMENT AND PROLIFERATION STAGES In vitro
}

\author{
Gehan Y.R. ; M.D. El-Deeb ${ }^{1}$ and I. Maksoud Ibrahim ${ }^{2}$
}

1. Dept. Plant Prod., Fac. Environ. Agri. Sc., Suez Canal Univ., Egypt.

2. Inst. Genetic Eng. and Biotechnol., Sadat City, Monofia Univ., Egypt.

\begin{abstract}
Embryo, Shoot tip and one node cutting from bitter and sweet almond are excised; sterilized, and cultured on Murashige \& Skoog (MS) medium. Also, different cytokinin types were evaluated. The obtained results showed that culturing of embryo on free MS medium was effective in enhancing establishment stage of bitter almond. However, sweet almond was enhanced by MS medium supplemented with BAP. Meanwhile, adding $1.0 \mathrm{mgl}^{-1}$ BAP for bitter almond and $2.0 \mathrm{mgl}^{-1}$ BAP for sweet almond encouraged the highest proliferation.
\end{abstract}

Key words: Explant types, Establishment, Proliferation Stage, micropropagation, Bitter and Sweet Almond rootstock, peach, BAP.

\section{INTRODUCTION}

Peach is sensitive to drought stress, as it can't be cultivated under new reclaimed areas conditions. So, bitter and sweet almond can be used as rootstocks for peach cultivation under these areas.

Peach considered one of the most important crops for farmers in North Sinai Peach trees are actually plagued by so many different pests and diseases and about 20\% or more from Peach fruits were lost through packaging and transportation processes, because it has soft skin and juicy flesh. Thus, Peach need more work of breeding and genetics to improve peach quality.

The peach (Prunus persica L.) is known as a species of Prunus native to China that bears an edible juicy fruit also called a peach. It is classified with the almond in the subgenus Amygdalus within the genus Prunus, Micropropagation offers the potential for mass production of own-rooted Peach, which may be useful as rootstock for virus indexing, and can accelerate screening for disease resistance. Shoot tips and onenode cuttings are the usual explants.

\footnotetext{
* Corresponding author: Tel.: +201007417921

E-mail address: gyousre@yahoo.com
}

For commercial micropropagation of virus-free plants of the Peach rootstocks "Istara', GF677, 'Penta', 'Tetra', 'MrS' 'Fire Cadman', 'Barrierl' Gensia' and 'Julior' (Battistini and De Paoli, 2002). Cytokinin like BAP, Kinetin, and $2 \mathrm{iP}$ at concentrations ranging from 1 to $10 \mathrm{mgl}^{-1}$ have proven effective for the induction of high frequency shoot bud/ shoot multiplication. Auxins like IAA, IBA, and NAA at the concentrations ranging from $0.1-2 \mathrm{mgl}^{-1}$ when used along with cytokinin are known to enhance the growth (Chahal and Gosal, 2002).

This work was carried out to improve micro propagation of bitter and sweet almond by culturing different explants types on media contains different cytokinines.

\section{MATERIALS AND METHODS}

This study was carried out in Plant Tissue Culture Laboratory, Faculty of Environmental Agricultural Sciences (FEAS), El-Arish, North Sinai, Suez Canal University (SCU). 
This study aimed to improve micro propagation of bitter and sweet almond rootstocks by culturing different explant types with different cytokinin.

\section{Plant Material}

Shoot tip, one-node cuttings about (0.5$0.75 \mathrm{~cm}$ ) and mature seeds were collected from mother plants of bitter and sweet Almond (Prunus amygdalus). (1-3 years old) during the active growth period (from March to July) from Rafah region, North Sinai.

\section{Explants Sterilization}

Shoot tip, one-node cutting and mature seeds were rinsed under running tap water with soap for 60 minutes to remove all the remaining detergent Then washed with sterilized distilled water. The explants were soaked for $20 \mathrm{~min}$ in $20 \%$ commercial bleach of Clorox solution $(5.25 \% \mathrm{NaOCl})$, then washed 3-4 times with sterilized distilled water to remove all traces of the disinfections. Embryos were left in water for 24 hour. All sterilization steps had been done under aseptic conditions inside the culture cabinet (Laminar air flow hood) using sterilized instruments. The experiments were carried out as follows:

\section{Establishment Stage}

Three explants (Embryo, shoot tips and one node cuttings) were cultured on MS Addition 6-benzylaminopurine (BAP) at $1.50 \mathrm{mgL}^{-1}$ comparison with hormone free medium was tested in combination with three explants (embryo, shoot tips and one node cuttings) to find out the best additive and best explants type.

All cultures contained Murashige and Skoog (1962) inorganic salts. Base/medium supplemented supplemented with BAP (6Benzyl amino Purine) at 0.0 and $1.5 \mathrm{mgl}^{-1}$ with addition of $0.1 \mathrm{gl}^{-1}$ myo-inositol, 30.0 $\mathrm{gL}^{-1}$ sucrose and sodified with $7.0 \mathrm{gl}^{-1}$ Agar. The $\mathrm{pH}$ of the medium was adjusted to 5.7 and autoclaved at $1.2 \mathrm{kgcm}^{-2}$ and $121^{\circ} \mathrm{C}$ for 20 minutes.

\section{Proliferation Stage}

\section{Effect of Cytokinin Type}

This stage aimed to increase the number of shoots. The shoot tip of the two almond rootstocks were cultured on MS media supplemented with $0.1 \mathrm{gl}^{-1}$ myo-inositol, $30.0 \mathrm{gl}^{-1}$ sucrose and $7.0 \mathrm{gl}^{-1}$ Agar.

As a basal medium kinetin (Kin), 6-benzyl amino purine (BAP), 2-isopentenyl adenine (2iP) and Zeatin were supplemented to the basal medium at the rate of $1 \mathrm{mgl}^{-1}$ detect the best cytokinin was able to induce, the highest multiplication after two subcultures.

\section{Effect of BAP Concentration}

Shoot tip of bitter and sweet almond (Prunus amygdalus) rootstocks were cultured on basal solid MS medium supplemented with different BAP concentrations at 0.0 , $0.5,1.0,1.5$ and $2.0 \mathrm{mgl}^{-1}$ plus $0.1 \mathrm{mgl}^{-1} \mathrm{IBA}$ to investigate the most suitable concentration induced the highest multiplication rate.

\section{Cultural Conditions}

The sterilized explants were cultured on the media under complete aseptic conditions in the Laminar Air Flow Hood and after that the cultured explants were incubated under $16 \mathrm{hrs}$ of artificial light and $8 \mathrm{hrs}$ dark at average temperature of $25 \pm 2^{\circ} \mathrm{C}$ provided by cool white fluorescent lamps (light intensity 2500 lux). The cultures were subcultured monthly. Also, measuring the data recorded after 4 weeks.

\section{Statistical Analysis}

Experiments were set up in complete randomized design (CRD) with four replicates. Data tested using the analysis of variance (ANOVA) by using SAS (SAS, 2004). The significant difference was observed for a measured value, means were separated using Duncan's multiple range test (DMRT) (Duncan, 1995) at the 5\% level. 


\section{RESULTS AND DISCCUSIONS}

\section{Establishment Stage}

Data in Table (1) reflected that there is no significant difference between free hormone and addition of hormones to MS medium when all parameters for bitter and sweet almond considered except the average of number of leaves leaf number in sweet almond.

The highest average leaf number (8.56) for sweet almond achieved on MS basal medium. The above mentioned results confirm the findings of Kassim et al. (2010) on bitter almond. They indicated that the MS medium achieved the best plant growth in establishment stage in peach.

On the other hand, Battistini and De Paoli (2002) reported that salts based Quoirin and Lepoivre medium (QLM) was more suitable for some peach rootstocks. Moreover, Andreu and Marı'n (2005) on Prunus rootstock found that WPM achieved the best plant growth in establishment period comparing to MS basal medium. Data in Table (2) indicated that the best explant type was embryos cultured on MS medium as compared with shoot tip and one node cuttings. The height of the plants were $(3.23$ and $3.45 \mathrm{~cm})$ for both bitter and sweet almond respectively, in embryos cultured on MS compared with others explants. Also, the highest number of leaves were (15.33and 12.40) for both bitter and sweet almond rootstocks respectively, in embryos cultured on MS compared with others explants.

However there is no significant difference among embryos, shoot tip and one node cutting on necrosis and greening parameters.

The findings of the current study are consistent with those reported by Andreu and Marim (2004) on Adesoto 101 (Prunus insititia) rootstock and El-Hammady et al. (2005) on almond. On the other hand
Kassim et al. (2010) found that one node cuttings surpassed shoot-tip in In vitro growth of bitter almond.

It is noticed from Table (3) that culturing of embryos on MS medium without addition of BAP achieved the highest plant length $(3.80 \mathrm{~cm})$ and leaf number (14.50) followed by embryos cultured on MS medium supplemented with BAP. The lowest necrosis appeared in embryos cultured in both MS either BAP or not.

For greening parameter significancy disappeared for all combination between BAP addition and explant types. While, addition of BAP at $1.5 \mathrm{mgl}^{-1}$ gained the best growth parameters. i.e., main plant length $(4.13 \mathrm{~cm})$ and number of leaves (13.67) for embryo sweet almond rootstock.

No significant effect was observed between different combinations when necrosis and greening parameters were concerned. Confirm the findings Isıkalan et al. (2008). Resulted the effect of BAP and kinetin on the culture initiation of zygotic embryos isolated from mature embryos. Murashige and Skoog (MS) medium containing $30 \mathrm{gl}^{-1}$ sucrose, 0.5 and $1.0 \mathrm{mgl}^{-1}$ N6-benzylaminopurine (BAP) and $7 \mathrm{gl}^{-1}$ agar enhanced multiple shoot initiation. On the other hand, Yapar et al. (2006) found that the best nodal Explant development occurred with MS contained $2.0 \mathrm{mgl}^{-1}$ (BAP) and $0.5 \mathrm{mgl}^{-1}$ IAA of Amygdalus comMunis. L cultivars.

\section{Proliferation Stage}

\section{Effect of Cytokinin Type}

Data in Table (4) clear that the development of plant length, numbers of leaves and shoot numbers, leaf per shoot and shoot length were developed by the four cytokinins tested BAP was superior in enhancing all parameters than Kin, 2ip and Zeatin but Kin was the best in plant length, Zeatin was the best in shoot length this may be due to that BAP is more efficient as cytokinin than Kin, 2ip and Zeatin for bitter 
Table (1): Effect of BAP Concentrations on growth and development of bitter and sweet almond during establishment stage.

\begin{tabular}{ccccccccc}
\hline Plant & \multicolumn{3}{c}{ Bitter almond } & \multicolumn{3}{c}{ Sweet almond } \\
\cline { 2 - 8 } Medium & $\begin{array}{c}\text { Main shoot } \\
\text { length (cm) }\end{array}$ & $\begin{array}{c}\text { No. } \\
\text { leaves }\end{array}$ & Necrosis Greening & $\begin{array}{c}\text { Main shoot } \\
\text { length (cm) }\end{array}$ & $\begin{array}{c}\text { No. } \\
\text { leaves }\end{array}$ & Necrosis Greening \\
\hline $\begin{array}{c}\text { MS basal medium } \\
\text { MS Plus BAP } \\
\left(\mathbf{1 . 5 m g l ^ { - 1 } )}\right.\end{array}$ & $2.24^{\mathrm{a}}$ & $9.57^{\mathrm{a}}$ & $0.55^{\mathrm{a}}$ & $4.45^{\mathrm{a}}$ & $2.46^{\mathrm{a}}$ & $8.56^{\mathrm{a}}$ & $1.19^{\mathrm{a}}$ & $3.81^{\mathrm{a}}$ \\
& $1.88^{\mathrm{a}}$ & $9.95^{\mathrm{a}}$ & $0.55^{\mathrm{a}}$ & $4.45^{\mathrm{a}}$ & $2.46^{\mathrm{a}}$ & $7.63^{\mathrm{b}}$ & $0.93^{\mathrm{a}}$ & $4.07^{\mathrm{a}}$
\end{tabular}

Means followed by the same letter within each column are not significantly different at 0.05 level of probability according to Duncan's multiple range test.

Table (2): Effect of different explants on development and growth of bitter and sweet almond rootstocks.

\begin{tabular}{ccccccccc}
\hline Rootstock & \multicolumn{3}{c}{ Bitter almond } & \multicolumn{3}{c}{ Sweet almond } \\
\hline Parameter & $\begin{array}{c}\text { Main } \\
\text { shoot } \\
\text { length } \\
\text { Explant }\end{array}$ & $\begin{array}{c}\text { No. } \\
\text { leaves }\end{array}$ & Necrosis & Greening & $\begin{array}{c}\text { Main } \\
\text { shoot } \\
\text { length } \\
(\mathbf{c m})\end{array}$ & & & $\begin{array}{c}\text { No. } \\
\text { leaves }\end{array}$ \\
Embryo & $3.23^{\mathrm{a}}$ & $15.33^{\mathrm{a}}$ & $0.50^{\mathrm{a}}$ & $4.50^{\mathrm{a}}$ & $3.45^{\mathrm{a}}$ & $12.40^{\mathrm{a}}$ & $1.20^{\mathrm{a}}$ & $3.80^{\mathrm{a}}$ \\
Shoot tip & $2.16^{\mathrm{b}}$ & $8.83^{\mathrm{b}}$ & $0.56^{\mathrm{a}}$ & $4.44^{\mathrm{a}}$ & $2.50^{\mathrm{b}}$ & $7.33^{\mathrm{b}}$ & $0.75^{\mathrm{b}}$ & $4.25^{\mathrm{a}}$ \\
One- node cutting & $0.93^{\mathrm{c}}$ & $6.19^{\mathrm{b}}$ & $0.57^{\mathrm{a}}$ & $4.43^{\mathrm{a}}$ & $1.30^{\mathrm{c}}$ & $4.39^{\mathrm{c}}$ & $1.33^{\mathrm{a}}$ & $3.67^{\mathrm{a}}$ \\
\hline
\end{tabular}

Means followed by the same letter within each column are not significantly different at 0.05 level of probability according to Duncan's multiple range test.

Table (3): Effect of the interaction between medium and explant types on development and growth for bitter and sweet almond.

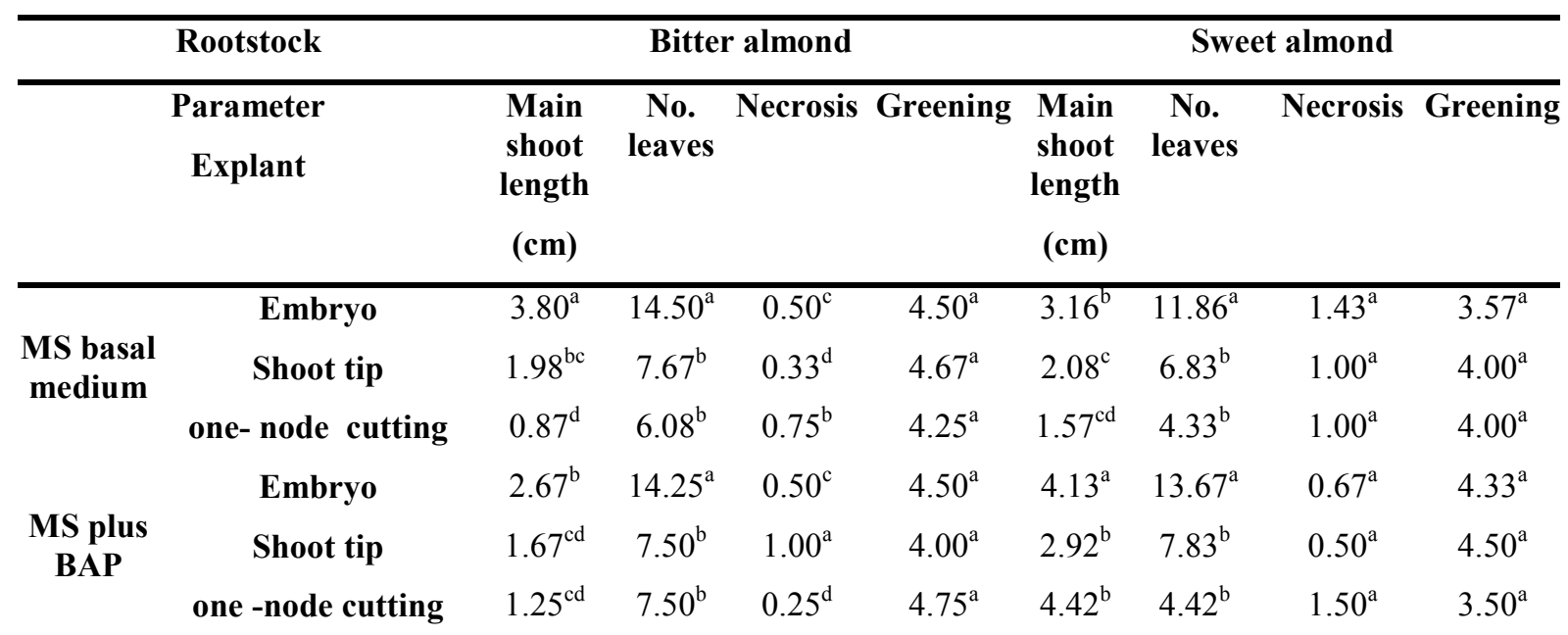

Means followed by the same letter within each column are not significantly different at 0.05 level of probability according to Duncan's multiple range test. 
SINAI Journal of Applied Sciences (ISSN: 2314-6079), Vol. (5), Is. (1), Apr. 2016

Table (4): Effect of cytokinin type on plant length, leaf number and shoot numbers, leaf per shoot, shoot length, necrosis and greening for bitter almond.

\begin{tabular}{|c|c|c|c|c|c|c|c|c|}
\hline Subculture & Cytokinin & $\begin{array}{l}\text { Main shoot } \\
\text { length } \\
\text { (cm) }\end{array}$ & $\begin{array}{c}\text { No. } \\
\text { leaves }\end{array}$ & $\begin{array}{c}\text { Axial } \\
\text { Shoot } \\
\text { number }\end{array}$ & $\begin{array}{l}\text { No. Leaf / } \\
\text { shoot }\end{array}$ & $\begin{array}{c}\text { Axial } \\
\text { Shoot length } \\
\text { (cm) }\end{array}$ & Necrosis & Greening \\
\hline \multirow[t]{6}{*}{$\overline{\text { Sub }_{1}}$} & Control & $2.925^{\mathrm{a}}$ & $18.500^{\mathrm{a}}$ & $0.750^{\mathrm{a}}$ & $4.375^{\mathrm{a}}$ & $0.850^{\mathrm{a}}$ & $1.000^{\mathrm{b}}$ & $4.000^{\mathrm{a}}$ \\
\hline & BAP & $2.075^{\mathrm{a}}$ & $13.000^{\mathrm{b}}$ & $0.500^{\mathrm{a}}$ & $3.750^{\mathrm{b}}$ & $0.650^{\mathrm{a}}$ & $0.750^{\mathrm{b}}$ & $4.250^{\mathrm{a}}$ \\
\hline & 2ip & $2.650^{\mathrm{a}}$ & $10.500^{\mathrm{c}}$ & $0.000^{\mathrm{b}}$ & $0.000^{c}$ & $0.000^{\mathrm{b}}$ & $1.000^{\mathrm{b}}$ & $4.000^{\mathrm{a}}$ \\
\hline & Zeatin & $2.060^{\mathrm{a}}$ & $8.800^{\mathrm{d}}$ & $0.000^{\mathrm{b}}$ & $0.000^{c}$ & $0.000^{\mathrm{b}}$ & $1.200^{\mathrm{b}}$ & $4.000^{\mathrm{a}}$ \\
\hline & Kin & $2.575^{\mathrm{s}}$ & $12.000^{\mathrm{b}}$ & $0.250^{\mathrm{a}}$ & $1.500^{\mathrm{a}}$ & $0.300^{\mathrm{a}}$ & $0.500^{\mathrm{b}}$ & $4.500^{\mathrm{a}}$ \\
\hline & Mean & 2.457 & 12.56 & 0.3 & 1.925 & 0.36 & 4.15 & 0.89 \\
\hline \multirow[t]{6}{*}{$\mathrm{Sub}_{2}$} & Control & $2.850^{\mathrm{a}}$ & $13.250^{\mathrm{b}}$ & $0.750^{\mathrm{a}}$ & $2.958^{\mathrm{b}}$ & $0.762^{\mathrm{a}}$ & $0.500^{\mathrm{b}}$ & $4.500^{\mathrm{a}}$ \\
\hline & BAP & $1.980^{\mathrm{a}}$ & $12.800^{\mathrm{b}}$ & $1.000^{\mathrm{a}}$ & $1.520^{\mathrm{b}}$ & $0.328^{\mathrm{a}}$ & $1.200^{\mathrm{b}}$ & $3.800^{\mathrm{a}}$ \\
\hline & 2ip & $2.900^{\mathrm{a}}$ & $17.667^{\mathrm{a}}$ & $0.333^{\mathrm{a}}$ & $3.000^{\mathrm{b}}$ & $0.500^{\mathrm{a}}$ & $3.333^{\mathrm{a}}$ & $1.666^{\mathrm{b}}$ \\
\hline & Zeatin & $2.100^{\mathrm{a}}$ & $8.400^{\mathrm{d}}$ & $0.000^{\mathrm{b}}$ & $0.000^{\mathrm{c}}$ & $0.000^{\mathrm{b}}$ & $1.400^{\mathrm{b}}$ & $3.600^{\mathrm{a}}$ \\
\hline & Kin & $2.050^{\mathrm{a}}$ & $10.500^{\mathrm{c}}$ & $0.500^{\mathrm{a}}$ & $2.333^{\mathrm{b}}$ & $0.600^{\mathrm{a}}$ & $1.166^{\mathrm{b}}$ & $3.833^{\mathrm{a}}$ \\
\hline & Mean & 2.376 & 12.523 & 0.517 & 1.962 & 0.438 & 3.479 & 1.519 \\
\hline
\end{tabular}

Means followed by the same letter within each column are not significantly different at 0.05 level of probability according to Duncan's multiple range test.

almond. Supplemented MS medium with BAP promoted maximum No. leaf (17.87), No. shoot (1.00) and the best value for plant length (3.23) was obtained with Kin than shoot length with Zeatin (1.44).

The different cytokinins were not significant in greening and necrosis. These results are in agreement with those of Silva et al. (2003) reported that BAP gave the highest in vitro multiplication rate for peach rootstocks. On the other hand, Islkalan et al. (2008) found that kinetin also induced multiple shoots, but not as effectively as the BAP.

Data in Table (5) indicated that the best was obtained of BAP at (Number of leaves, Axial Shoot number and Number of leaves/ shoot) for bitter almond (22.20, 1.20 and 4.50 respectively). While addition of Kin at $1 \mathrm{mgl}^{-1}$ recorded the highest plant $3.22 \mathrm{~cm}$.

On the other hand, different other cytokinins under study failed to induce statististcal differences. The superiority of BAP at $1 \mathrm{mgl}^{-1}$ was noticed for shoot multiplication in bitter almond.

The outlined data in Table (6) verify the best multiplication parameters and growth performance for sweet almond. Data clear that addition of BAP gave the highest values of number of shoots and number of leaves (0.777). Furthermore, control recorded the highest values for other.

Data in Table (7) showed that MS basal medium for sweet almond rootstock recorded the highest values of plant length, Number of leaves, shoots number, Number of leaves/shoot and Axial shoot length $(2.925,18.500,0.750,4.375$ and 0.850$)$ respectively at first subculture. While 2ip gave the highest plant length, leaf number (2.900, 17.667), respectively.

The maximum number of shoots was obtained from BAP addition at the second subculture. Regarding greening and necrosis 
Table (5): Effect of the interaction between cytokinin types and subcultures on of bitter almond during proliferation stage.

\begin{tabular}{cccccccc}
\hline $\begin{array}{c}\text { Cytokinin } \\
\left(\mathbf{m g l}^{-1}\right)\end{array}$ & $\begin{array}{c}\text { Main shoot } \\
\text { length } \\
(\mathbf{c m})\end{array}$ & $\begin{array}{c}\text { No. } \\
\text { leaves }\end{array}$ & $\begin{array}{c}\text { Axial shoot No. leaves/ } \\
\text { number }\end{array}$ & $\begin{array}{c}\text { Axial shoot } \\
\text { shoot } \\
\text { length } \\
(\mathbf{c m})\end{array}$ & \multicolumn{2}{c}{ Necrosis Greening } \\
\hline Control & $2.900^{\mathrm{ab}}$ & $10.667^{\mathrm{b}}$ & $0.333^{\mathrm{ab}}$ & $1.500^{\mathrm{ab}}$ & $0.616^{\mathrm{ab}}$ & $0.666^{\mathrm{a}}$ & $4.333^{\mathrm{a}}$ \\
BAP & $1.975^{\mathrm{b}}$ & $17.875^{\mathrm{a}}$ & $1.000^{\mathrm{a}}$ & $3.938^{\mathrm{a}}$ & $0.651^{\mathrm{ab}}$ & $0.665^{\mathrm{a}}$ & $4.375^{\mathrm{a}}$ \\
$\mathbf{K i n}$ & $3.228^{\mathrm{a}}$ & $14.667^{\mathrm{ab}}$ & $0.428^{\mathrm{ab}}$ & $1.786^{\mathrm{ab}}$ & $0.442^{\mathrm{ab}}$ & $0.857^{\mathrm{a}}$ & $4.083^{\mathrm{a}}$ \\
$\mathbf{2 i p}$ & $2.180^{\mathrm{ab}}$ & $10.700^{\mathrm{b}}$ & $0.800^{\mathrm{ab}}$ & $2.900^{\mathrm{ab}}$ & $0.885^{\mathrm{ab}}$ & $0.900^{\mathrm{a}}$ & $4.100^{\mathrm{a}}$ \\
Zeatin & $2.285^{\mathrm{ab}}$ & $14.000^{\mathrm{ab}}$ & $0.571^{\mathrm{ab}}$ & $1.171^{\mathrm{ab}}$ & $1.435^{\mathrm{a}}$ & $1.000^{\mathrm{a}}$ & $4.000^{\mathrm{a}}$ \\
\hline
\end{tabular}

Means followed by the same letter within each column are not significantly different at 0.05 level of probability according to Duncan's multiple range test.

Table (6): Effect of cytokinin types on sweet almond rootstock growth during proliferation stage.

\begin{tabular}{cccccccc}
\hline Cytokine & $\begin{array}{c}\text { Main shoot } \\
\text { length } \\
\text { (cm) }\end{array}$ & No. leaves & $\begin{array}{c}\text { Axial } \\
\text { shoot } \\
\text { number }\end{array}$ & $\begin{array}{c}\text { No. leaves } \\
\text { /shoot }\end{array}$ & $\begin{array}{c}\text { Axial shoot } \\
\text { length } \\
\text { (cm) }\end{array}$ & Necrosis Greening \\
\hline Control & $2.875^{\mathrm{a}}$ & $15.000^{\mathrm{a}}$ & $0.750^{\mathrm{a}}$ & $3.430^{\mathrm{a}}$ & $0.791^{\mathrm{a}}$ & $0.666^{\mathrm{b}}$ & $4.333^{\mathrm{a}}$ \\
BAP & $2.022^{\mathrm{b}}$ & $12.889^{\mathrm{a}}$ & $0.777^{\mathrm{a}}$ & $2.511^{\mathrm{ab}}$ & $0.471^{\mathrm{ab}}$ & $1.000^{\mathrm{b}}$ & $4.000^{\mathrm{a}}$ \\
$\mathbf{2 i p}$ & $2.757^{\mathrm{ab}}$ & $13.571^{\mathrm{a}}$ & $0.142^{\mathrm{a}}$ & $1.286^{\mathrm{ab}}$ & $0.214^{\mathrm{ab}}$ & $2.000^{\mathrm{a}}$ & $3.000^{\mathrm{b}}$ \\
Zeatin & $2.080^{\mathrm{ab}}$ & $8.600^{\mathrm{b}}$ & $0.000^{\mathrm{b}}$ & $0.000^{\mathrm{c}}$ & $0.000^{\mathrm{c}}$ & $1.300^{\mathrm{ab}}$ & $3.800^{\mathrm{a}}$ \\
Kin & $2.260^{\mathrm{ab}}$ & $11.100^{\mathrm{a}}$ & $0.400^{\mathrm{a}}$ & $2.000^{\mathrm{ab}}$ & $0.480^{\mathrm{ab}}$ & $0.900^{\mathrm{b}}$ & $4.100^{\mathrm{a}}$
\end{tabular}

Means followed by the same letter within each column are not significantly different at 0.05 level of probability according to Duncan's multiple range test.

Table (7): Effect of the interaction between cytokinin types and subcultures on plant length, leaf and shoot numbers, leaf per shoot, shoot length, necrosis and greening for sweet almond.

\begin{tabular}{|c|c|c|c|c|c|c|c|}
\hline $\begin{array}{l}\text { Parameter } \\
\text { BAP concentration } \\
\left(\mathrm{mgl}^{-1}\right)\end{array}$ & $\begin{array}{l}\text { Main shoot } \\
\text { length } \\
\text { (cm) }\end{array}$ & $\begin{array}{c}\text { No. } \\
\text { leaves }\end{array}$ & $\begin{array}{c}\text { Axial shoot } \\
\text { number }\end{array}$ & $\begin{array}{c}\text { No. Leaf/ } \\
\text { shoot }\end{array}$ & $\begin{array}{c}\text { Axial shoot } \\
\text { length } \\
\text { (cm) }\end{array}$ & Greening & Necrosis \\
\hline Control & $3.700^{\mathrm{a}}$ & $19.667^{\mathrm{c}}$ & $0.333^{\mathrm{c}}$ & $2.667^{\mathrm{d}}$ & $0.833^{\mathrm{b}}$ & $4.000^{\mathrm{a}}$ & $1.000^{\mathrm{a}}$ \\
\hline 0.5 & $2.660^{\mathrm{ab}}$ & $26.600^{\mathrm{b}}$ & $2.200^{\mathrm{a}}$ & $4.694^{\mathrm{c}}$ & $1.996^{\mathrm{a}}$ & $3.800^{\mathrm{b}}$ & $1.200^{\mathrm{a}}$ \\
\hline 1 & $2.560^{\mathrm{ab}}$ & $32.667^{\mathrm{a}}$ & $2.333^{\mathrm{a}}$ & $8.890^{\mathrm{a}}$ & $1.650^{\mathrm{a}}$ & $4.500^{\mathrm{a}}$ & $0.500^{\mathrm{b}}$ \\
\hline 1.5 & $2.683^{\mathrm{ab}}$ & $29.500^{\mathrm{a}}$ & $1.667^{\mathrm{b}}$ & $6.875^{\mathrm{b}}$ & $1,283^{\mathrm{a}}$ & $4.500^{\mathrm{a}}$ & $0.500^{\mathrm{b}}$ \\
\hline 2 & $2.100^{\mathrm{b}}$ & $23.500^{\mathrm{b}}$ & $1.750^{\mathrm{b}}$ & $6.188^{\mathrm{b}}$ & $0.995^{\mathrm{b}}$ & $4.500^{\mathrm{a}}$ & $0.500^{\mathrm{b}}$ \\
\hline
\end{tabular}

Means followed by the same letter within each column are not significantly different at 0.05 level of probability according to Duncan's multiple range test. 
SINAI Journal of Applied Sciences (ISSN: 2314-6079), Vol. (5), Is. (1), Apr. 2016

the results of both subcultures indicated that there were no differences between different cytokinins.

These results are similar to those obtained by superior results in response to BAP for shoot induction compared to other cytokinins have been reported in different Prunus species (Leontiev-Orlov et al. 2000).

\subsection{Effect of BAP concentrations}

Data in Table (8) indicated that highest shoot production was produced by addition BAP at $1 \mathrm{mgl}^{-1}$ with IBA at $0.1 \mathrm{mgl}^{-1}$ for bitter almond. Asil achived the best multiple shoot (2.3). Also greatest number of leaves/ shoot (8.8) but the highest shoot length (1.9) was recorded by addition of 0.5 $\mathrm{mgl}^{-1}$ BAP combined with IBA at $0.1 \mathrm{mgl}^{-1}$. These results are similar to those obtained by Leontiev-Orlov et al. (2000), Silva et al (2003) and Tornero and Burgos (2000). They observed that increasing levels of cytokinins inhibited shoot elongation in plum trees.

Also, Kamali et al. (2001) showed the best result for proliferation by using of BA at $1 \mathrm{mgl}^{-1}$ level. On the other hand, Isikalan et al. (2008), Imani and Abdollahi (2006) mentioned that Increasing BAP concentrations from 1 to $2 \mathrm{mgl}^{-1}$ caused more proliferation and long survival of hybrids.

The best treatment for shoot proliferation was $4 \mathrm{mgl}^{-1} \mathrm{BAP}+0.5 \mathrm{mgl}^{-1} \mathrm{GA}_{3}$ without significant difference with the medium containing $2 \mathrm{mgl}^{-1}$ BAP. Results in Table (9) presented that the increasing BAP concentrations from 1 to $2 \mathrm{mgl}^{-1}$ caused more proliferation for sweet almond. The maximum No. of leaves, No. of shoots, No. leaf/ shoot, shoot length and greening obtained on MS medium supplemented with BAP at $2 \mathrm{mgl}^{-1}$ except plant length where the highest value $(2.8 \mathrm{~cm})$ was recorded with $0.5 \mathrm{mgl}^{-1}$ BAP. The findings of the current study are consistent with those reported by Khosravi and Farhadi (2011) on HS314 rootstock, Mahmood et al (2009) on Peach and Yapar et al. (2006) They revealed that the highest number of shoots produced on a medium containing 2 $\mathrm{mgl}^{-1}$ BAP. Also, Silva et al., (2003) on Prunus 'Capdeboscq' rootstocks observed that BAP gave the highest in vitro multiplication rate (25.9 shoots/explants at the rate of $\left.1.5 \mathrm{mgl}^{-1}\right)$.

Table (8): Effect of BAP concentrations combined with IBA at $0.1 \mathrm{mgl}^{-1}$ on growth and proliferation rate of bitter almond rootstock during proliferation stage.

\begin{tabular}{|c|c|c|c|c|c|c|c|c|}
\hline 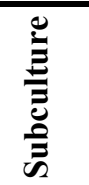 & 量 & $\begin{array}{l}\text { Main shoot } \\
\text { length } \\
\text { (cm) }\end{array}$ & $\begin{array}{l}\text { Number of } \\
\text { leaves }\end{array}$ & $\begin{array}{c}\text { Axial shoot } \\
\text { number }\end{array}$ & $\begin{array}{c}\text { Number of } \\
\text { leaves } \\
\text { /shoot }\end{array}$ & $\begin{array}{l}\text { Axial shoot } \\
\text { length } \\
\text { (cm) }\end{array}$ & Necrosis & Greening \\
\hline \multirow{6}{*}{ Sub $_{1}$} & Control & $2.566^{\mathrm{ab}}$ & $9.333^{b}$ & $0.000^{b}$ & $0.000^{\mathrm{b}}$ & $0.000^{\mathrm{c}}$ & $0.333^{\mathrm{a}}$ & $4.666^{\mathrm{a}}$ \\
\hline & BAP & $1.566^{\mathrm{b}}$ & $10.667^{\mathrm{b}}$ & $0.666^{\mathrm{a}}$ & $3.000^{\mathrm{a}}$ & $0.533^{b}$ & $1.000^{\mathrm{a}}$ & $4.000^{\mathrm{a}}$ \\
\hline & kin & $2.420^{\mathrm{ab}}$ & $12.000^{\mathrm{b}}$ & $0.000^{\mathrm{b}}$ & $0.000^{\mathrm{b}}$ & $0.000^{\mathrm{c}}$ & $1.000^{\mathrm{a}}$ & $4.000^{\mathrm{a}}$ \\
\hline & 2ip & $2.225^{\mathrm{ab}}$ & $10.250^{\mathrm{b}}$ & $0.500^{\mathrm{a}}$ & $2.250^{\mathrm{a}}$ & $0.500^{\mathrm{b}}$ & $0.750^{\mathrm{a}}$ & $4.250^{\mathrm{a}}$ \\
\hline & Zeatin & $2.000^{\mathrm{b}}$ & $11.333^{\mathrm{b}}$ & $0.666^{\mathrm{a}}$ & $0.733^{\mathrm{a}}$ & $3.000^{\mathrm{a}}$ & $1.333^{\mathrm{a}}$ & $3.666^{\mathrm{a}}$ \\
\hline & Mean & 2.155 & 10.717 & 0.366 & 1.197 & 0.807 & 0.883 & 4.116 \\
\hline \multirow{6}{*}{$\mathrm{Sub}_{2}$} & Control & $2.233^{\mathrm{ab}}$ & $12.000^{\mathrm{b}}$ & $0.667^{\mathrm{a}}$ & $3.000^{\mathrm{a}}$ & $1.233^{\mathrm{b}}$ & $1.000^{\mathrm{a}}$ & $4.000^{\mathrm{a}}$ \\
\hline & BAP & $2.22^{\mathrm{ab}}$ & $22.200^{\mathrm{a}}$ & $1.200^{\mathrm{a}}$ & $4.500^{\mathrm{a}}$ & $0.722^{\mathrm{b}}$ & $0.400^{\mathrm{a}}$ & $4.600^{\mathrm{a}}$ \\
\hline & Kin & $3.228^{\mathrm{a}}$ & $16.571^{\mathrm{ab}}$ & $0.429^{\mathrm{ab}}$ & $1.786^{\mathrm{a}}$ & $0.442^{b}$ & $0.857^{\mathrm{a}}$ & $4.142^{\mathrm{a}}$ \\
\hline & $2 \mathrm{ip}$ & $2.150^{\mathrm{ab}}$ & $11.000^{\mathrm{b}}$ & $1.000^{\mathrm{a}}$ & $3.333^{\mathrm{a}}$ & $1.141^{\mathrm{b}}$ & $1.000^{\mathrm{a}}$ & $4.000^{\mathrm{a}}$ \\
\hline & Zeatin & $2.500^{\mathrm{ab}}$ & $16.000^{\mathrm{ab}}$ & $0.500^{\mathrm{a}}$ & $1.500^{\mathrm{a}}$ & $0.262^{\mathrm{b}}$ & $0.750^{\mathrm{a}}$ & $4.250^{\mathrm{a}}$ \\
\hline & Mean & 2.466 & 15.554 & 0.759 & 2.824 & 0.76 & 0.801 & 4.198 \\
\hline
\end{tabular}

Means followed by the same letter within each column are not significantly different at 0.05 level of probability according to Duncan's multiple range test. 
Table (9): Effect of BAP concentrations combined with IBA at $0.1 \mathrm{mgl}^{-1}$ on growth of sweet almond rootstocks during proliferation rate.

\begin{tabular}{cccccccc}
\hline $\begin{array}{c}\text { Parameter } \\
\text { Conce }\left(\mathbf{m g l}^{\mathbf{1}}\right)\end{array}$ & $\begin{array}{c}\text { Main shoot } \\
\text { length } \\
(\mathbf{c m})\end{array}$ & $\begin{array}{c}\text { Number of } \\
\text { leaves }\end{array}$ & $\begin{array}{c}\text { Axial shoot } \\
\text { number }\end{array}$ & $\begin{array}{c}\text { Leaf number } \\
\text { per shoot }\end{array}$ & $\begin{array}{c}\text { Axial shoot } \\
\text { length } \\
(\mathbf{c m})\end{array}$ & & \\
\hline Control & $2.200^{\mathrm{b}}$ & $10.250^{\mathrm{b}}$ & $0.250^{\mathrm{c}}$ & $1.250^{\mathrm{c}}$ & $0.400^{\mathrm{b}}$ & $3.750^{\mathrm{a}}$ & $1.250^{\mathrm{a}}$ \\
$\mathbf{0 . 5}$ & $2.833^{\mathrm{a}}$ & $15.500^{\mathrm{a}}$ & $0.667^{\mathrm{b}}$ & $2.667^{\mathrm{c}}$ & $0.683^{\mathrm{a}}$ & $4.000^{\mathrm{a}}$ & $1.000^{\mathrm{b}}$ \\
$\mathbf{1}$ & $2.200^{\mathrm{b}}$ & $13.833^{\mathrm{b}}$ & $0.667^{\mathrm{b}}$ & $4.167^{\mathrm{a}}$ & $0.842^{\mathrm{a}}$ & $3.500^{\mathrm{a}}$ & $1.500^{\mathrm{a}}$ \\
$\mathbf{1 . 5}$ & $2.080^{\mathrm{b}}$ & $14.000^{\mathrm{a}}$ & $0.600^{\mathrm{b}}$ & $1.200^{\mathrm{c}}$ & $0.260^{\mathrm{b}}$ & $3.400^{\mathrm{b}}$ & $1.600^{\mathrm{a}}$ \\
$\mathbf{2}$ & $2.640^{\mathrm{a}}$ & $17.400^{\mathrm{a}}$ & $3.000^{\mathrm{a}}$ & $5.866^{\mathrm{a}}$ & $1.660^{\mathrm{a}}$ & $4.000^{\mathrm{a}}$ & $1.000^{\mathrm{b}}$ \\
\hline
\end{tabular}

Means followed by the same letter within each column are not significantly different at 0.05 level of probability according to Duncan's multiple range test.

\section{REFERENCES}

Andreu, P. and Marin, J.A. (2004). Micropropagation enhances in vitro establishment and multiplication of new cultures from field grown plants of Adesoto 101 (Prunus insititia) rootstock. Acta-Hort., 658 (2): 605-609.

Andreu, P. and Marı'n, J.A. (2005). In vitro culture establishment and multiplication of the Prunus rootstock 'Adesoto 101' ( $P$. insititia L.) as affected by the type of propagation of the donor plant and by the culture. Medium Composition Scientia Hort., 106: 258267.

Battistini, A. and De Paoli, G. (2002). Large Scale Micropropagation of Several Peach Rootstocks. Acta Hort., 592: 29-35.

Chahal, G.S. and Gosal, S.S. (2002). Principles and Procedures of Plant Breedind Biotechnological and Conventional Approaches, 431-433.

Duncan, D.B. (1995). Multiple range and multiple F-test. Biometrics, 11: 1-42.

El-Hammady, A.; Wanas, W.H.; ElHamid, A.A. and El-Salem, M.J. (2005). In vitro propagation of three almond cultivar and the almond- 'peach hybrid rootstock" Hansen Arab
Universities, J. Agric. Sci., 13 (2): 481499.

Imani, A. and Abdollahi, H. (2006). In Vitro Clonal Propagation of Prunus persica L. $\times$ Prunus amygdalus Batsch. Hybrid Acta Hort. 726.

Istkalan, C.; Akba, F.A.; Naml, S.; Tilkat, E. and Basaran D. (2008). In vitro micropropagation of almond (Amygdalus communis L. cv. Nonpareil). Afri. J. Biotechnol., 7 (12): 1875-1880.

Kamali, K.; E. Majidi and R. Zarghami (2001). Micropropagation of GF-677 roots tocks (Prunus amygdalus $\mathrm{x} P$. persica) In: Ak B.E. (ed.). XI Grempa Seminar on Pistachios and Almonds. Zaragoza: Ciheam., 175-177.

Kassim, N.E.; Abou Rayya, S.M. and Ali E.A.M. (2010). effect of explants types and different basal nutrient media on in vitro growth of bitter almond cuttings during establishment and proliferation stages. J. Ame. Sci., 6(10): 408-411.

Khosravi, S. and Farhadi, S. (2011). In vitro propagation of HS314 Rootstock (Prunus amygdalus $\times$ P. Persica) Hort. Sci., 46 (6): 928-931.

Leontiev-Orlov, O.; Rogalski, M.; Mossi, A.J. and Cansian, R.L. (2000). 6Benzilaminopurina (BAP) na multiplicação 
in vitro de prunáceas (Prunus sp.). Revista Brasileira de Agrociência, 6: 63-67.

Mahmood, A.; Duhoky, M.M.S. and Salman, M.A. (2009). In vitro propagation of Peach (Prunus Persica L.) CV. Red June. J. Duhok Univ., 12 (11): 67-73.

Murashige, T. and Skoog, F. (1962). A revised medium for rapid growth and bioassays with tobacco tissue cultures. Physiol Plant, 15: 473-497.

SAS, Institute (2004). SAS User's Guide, version 4.0.2. SAS Inst., Cary, NC.

Silva, A.L. da; Rogalski, M. and Guerra, M.P. (2003). Effects of different cytokinins on in vitro multiplication of Prunus 'Capdeboscq' rootstocks. Crop Breed. and Appl. Biotechnol., 3 (2): 149156.

Tornero, P.O. and Burgos, L. (2000). Different media requirements for micropropagation of apricot cultivars. Plant Cell, Tissue and Organ Culture. 63: 133-141.

Yapar, H.; Can, C.; Ozaslan, M.; Aytekin, T. and Atli, H. (2006). Application of In vitro Tissue culture Techniques for propagation of Amygdalus communis L. Cultivars, Garrigues and Yaltsinki. Biotechnol., 5 (1): 49-52. 
تأثير نوع الجزء النباتي على نمو أصل اللوز المُر والحلو خلال مرحلة الإنشاء والتضاعف

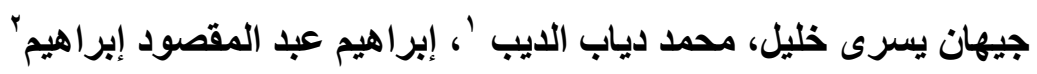

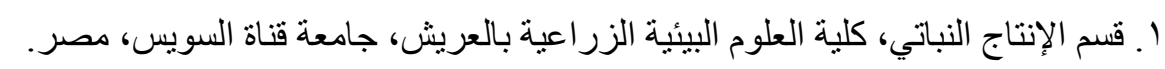

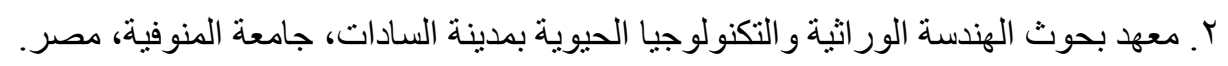

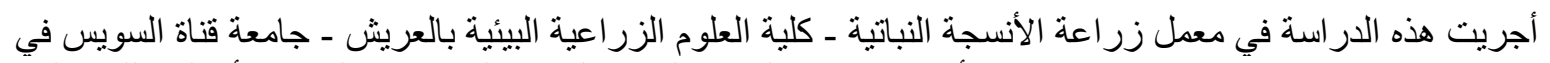

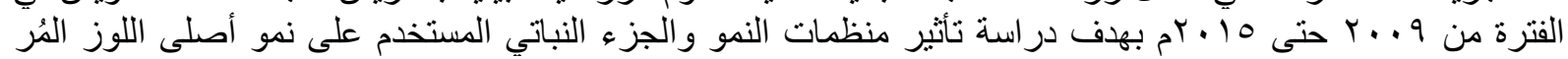

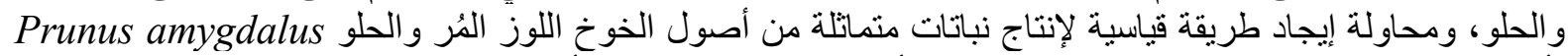

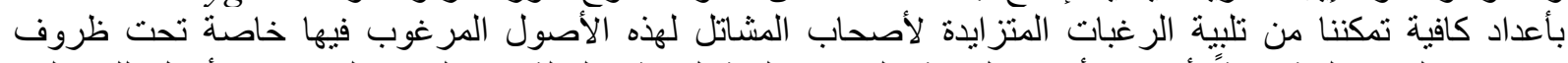

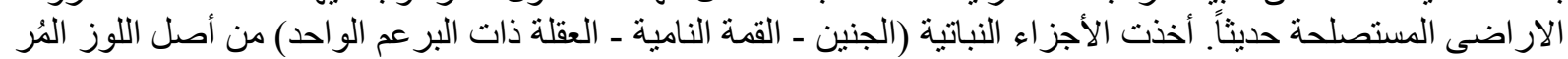

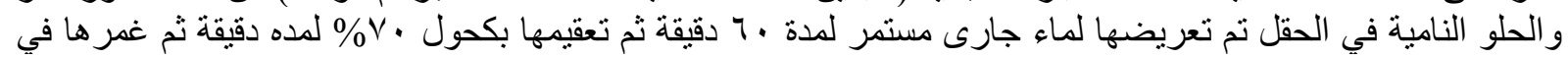

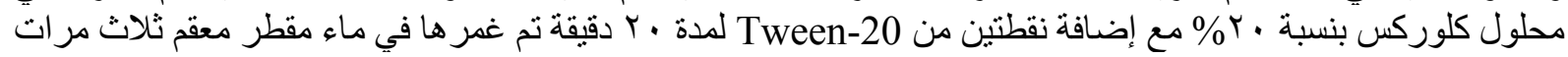

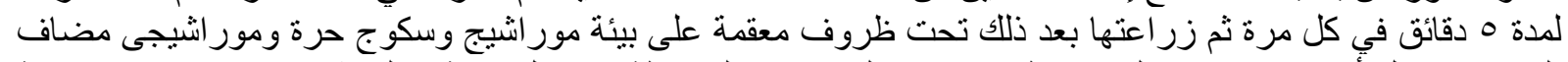

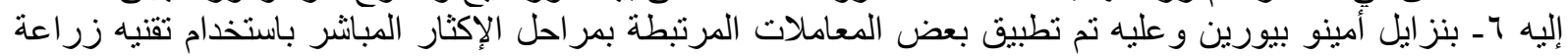

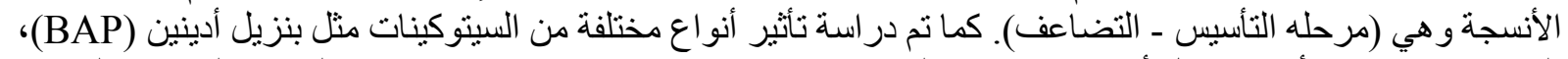

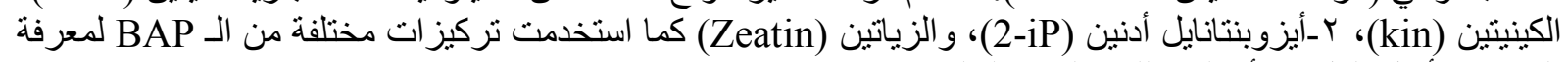

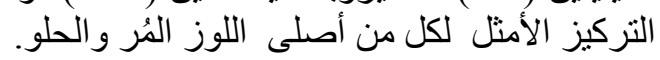

الكلمات الإسترشادية: نوع المنفصل النباتى، مرحلة الإنشاء، مرحله التضاعف، لإكثار الدقيق، أصل اللوز المُر والحلو، الخوخ. 